\title{
Evaluation of a potential candidate for heavy metal phytostabilization in polluted sites of the Mediterranean littoral (SE Marseille): endomycorrhizal status, fitness biomarkers and metal content of Atriplex halimus spontaneous populations
}

\author{
*Isabelle Laffont-Schwob, *Gabriel d'Enjoy-Weinkammerer, **Anca Pricop, \\ ***Pascale Prudent, *Véronique Masotti, *Jacques Rabier
}

*UMR CNRS IRD 6116 IMEP, Av. Escadrille Normandie-Niemen, case 441,

13397 Marseille Cedex 20, France

e-mail: isabelle.schwob@univ-provence.fr

**U.S.A.M.V.B. Timisoara, Faculty of Animal Sciences and Biotechnologies,

119 Calea Aradului, 300645 Timisoara, Romania

***LCP - UMR CNRS 6264, équipe Chimie de l'Environnement Continental (CEC), Université de Provence - case

29 - 3 place Victor Hugo - 13331 MARSEILLE cedex 3, France

Summary. This study showed that Atriplex halimus forms endomycorrhizae on heavy metal polluted-soils. But no variation of chlorophylls content in leaves was observed. Only low concentrations of heavy metals were found in leaves compared with the high levels of pollutants in the soil. A. halimus appears as a good candidate for phytostabilization of heavy metals in brackish soils.

Key words: Mediterranean saltbush, endosymbionts, heavy metal, phytoremediation.

\section{Introduction}

Atriplex halimus L., originated from North Africa, is a widespread Mediterranean shrub species (Ortíz-Dorda et al. 2005) with high resistance to various abiotic stresses included heavy metals (HM) (Lutts et al. 2004; Lefèvre et al. 2009). However, since this species shows a high genetic variability (Ortíz-Dorda et al. 2005), phytoextraction capacities may greatly vary from one population to another. Moreover, biotic parameters may also modify the phytoremedial potential of this species. Although Chenopodiaceae family is normally defined as non-mycorrhizal, more than 10 species of Atriplex genus were found to form endomycorrhizal associations (Sonjak et al. 2009). However, there is no report about the arbuscular mycorrhizal (AM) status of $A$. halimus. This study aimed to determine the occurrence of AM associations, HM, chlorophylls and flavonols contents of leaves of A. halimus in polluted soils and to define whether or not $A$. halimus is a good candidate for phytoremediation.

\section{The study area}

Spontaneous populations of A. halimus from three sites named Calanque de Saména, Calanque du Trou, and Cap Croisette were selected at the vicinity of the former industrial site of l'Escalette (Marseille, S-E France). 


\section{Research methods}

Root sampling was done on five individuals in each population. The percentage of mycorrhizal root length was estimated by visual observation of fungal colonisation after clearing washed roots in $10 \% \mathrm{KOH}$ and staining with lactophenol blue solution, according to Phillips and Hayman (1970). Fitness biomarkers were monitored using a nondestructive Multiplex ${ }^{\circledR}$ equipment that uses fluorescence technology with multiple excitations to measure chlorophylls and flavonols including anthocyans. By individual, 15 measurements were done on 5 plants by population. On leaves and soil samples, $\mathrm{Cd}, \mathrm{Cu}, \mathrm{Fe}, \mathrm{Pb}$, and $\mathrm{Zn}$ were analysed by ICP-AES, As was analysed by graphite furnace AAS and by flame AES were analysed Na and K. Transversal leaf sections were carbon metallized for observation under an ESEM Philips XL 30 microscope. The EDXS spectra for the compositional analyses and X-ray mapping were performed on the samples.

\section{Results and discussion}

In two out of the three sites, representative mycelia and vesicles were observed in the roots of all individuals. No variation of chlorophylls content in leaves was observed between the sites. Lower levels of anthocyans and total flavonols were observed in Cap Croisette individuals. Only low concentrations of HM were found in leaves compared with the high levels of pollutants in the soil. All stations appeared polluted from the industrial source. SEM coupled with elemental analysis did not enable to localise specific $\mathrm{HM}$ deposition in the leaf tissues. However, accumulation of $\mathrm{Na}, \mathrm{K}$ and $\mathrm{Cl}$ was revealed by this method in leaf glands relative to the salt accumulation ability of the species. As for $\mathrm{Na}$ and $\mathrm{Cl}$, the presence of highly detectable level of $\mathrm{Mg}$ and $\mathrm{S}$ is related to their abundance in seawater. To our knowledge it is the first SEM evidence of $\mathrm{Mg}$ and $S$ localization in salt glands. Considering the low traceelement translocation in the aerial parts, A. halimus appears as a good candidate for phytostabilization of HM in brackish soils of the Mediterranean coast. Previous studies of antagonism of metal versus salt on Atriplex genus focused on root absorption (Lefèvre et al. 2009) or adsorption of dead tissues (Sawalha et al. 2009). Our observations showed that leaf absorption of all the elements present in seaspray might also play a role in metal tolerance of Atriplex halimus submitted to metal polluted soils on the seashore. However as an alien species in France, its invasive potential has to be determined before a large scale-use.

\section{Acknowledgements}

The authors thank Soumia Djilalli, Cécile Evrard and Thomas Devenoges for their technical assistance of root preparation, Laurent Vassalo and Carine Demelas for their analytical assistance for HM measurements and the ANR for the Marséco program grant (2008 CESA 018).

\section{References}

Lefèvre I., Marchal G., Meerts P., Corréal E. \& Lutts S., 2009, Chloride salinity reduces cadmium accumulation by the Mediterranean halophyte species Atriplex halimus L., Environmental and Experimental Botany 65: $142-152$

Lutts S., Lefèvre I., Delpérée C., Kivits S., Dechamps C., Robledo A. \& Correal E., 2004, Heavy metal accumulation by the halophyte species Mediterranean saltbush, Journal of Environmental Quality 33: 1271-1279.

Ortíz-Dorda J., Martínez-Mora C., Correal E., Simón B. \& Cenis J. L., 2005, Genetic structure of Atriplex halimus populations in the Mediterranean Basin, Annals of Botany 95 : 827-834.

Phillips J. M. \& Hayman D. S., 1970, Improved procedures for clearing roots and staining parasitic and vesicular arbuscular mycorrhizal fungi for rapid assessment of infection, Transactions of the British Mycological Society 55: 159-61.

Sawalha M. F., Peralta-Videa J. R., Sanchez-Salcido B. \& Gardea-Torresdey J. L., 2009, Sorption of hazardous metals from single and multi-element solutions by saltbush biomass in batch and continuous mode: Interference of calcium and magnesium in batch mode, Journal of Environmental Management 90: 1213-1218.

Sonjak S., Udovic M., Wraber T., Likar M. \& Regvar M., 2009, Diversity of halophytes and identification of arbuscular mycorrhizal fungi colonising their roots in an abandoned and sustained part of Secovlje saltern, Soil Biology \& Biochemistry 41: 1847-1856. 